\title{
Impact of KVK Trainings on Promotion of Backyard Poultry Farming In Kalyan-Karnataka
}

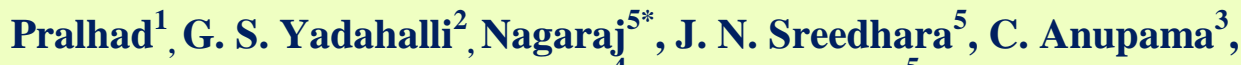 \\ G. N. Shreevani ${ }^{4}$ and M. C. Patil ${ }^{5}$ \\ ${ }^{1}$ Department of Animal Science, ${ }^{3}$ CAE, UAS, Raichur-584 104, India \\ ${ }^{3}$ Department of Home Science, ${ }^{4}$ Department of Agricultural Entomology, \\ ${ }^{5}$ ICAR-KVK, University of Agricultural Sciences, Raichur-584 104, Karnataka, India \\ *Corresponding author
}

\section{A B S T R A C T}

In recent years, backyard poultry production has been extremely emphasized in sustaining and enhancing rural livelihoods for rural youth. In this farming, birds are kept in low-input and low- output system and can easily be managed by women and children of the households. Now-a-days as there is growing concern about meeting of per capita requirement of protein for rural citizens of India, poultry meat and especially eggs have been proved to be the best and cheapest solution to this as it is the best alternative for the small scale farmers to their subsidiary income with negligible input, this farming system needs an upliftment. Therefore a present study was undertaken in Karnataka Agriculture Price Commission (KAPC) adopted village of Jakkaladinni, Manavi (Tq) Raichur (Dist), Karnataka to know the impact of trainings on scientific method of backyard poultry farming among small and marginal poultry farmers participated in KVK Raichur for training programme. Collection of data regarding gain in knowledge and adopted level about improved poultry science technologies in backyard poultry farming were recorded before and after trainings. The findings revealed that the knowledge about new variety (96.67\%). It was also found that majority $93.33 \%$ farmers gained knowledge in housing system (semi intensive and intensive) followed by balanced poultry feed $(90.00 \%)$, vaccination (F-1) (83.33\%), deworming (76.67\%), lime stone grit feeding $(63.33 \%)$, Scavenging habit $(56.67 \%)$ and azolla feeding $(40.00 \%)$ respectively. The current Study showed that very few farmers were known about scientific method of backyard poultry farming before training whereas, after training the level of adoption increases in new breed $40.00 \%$, balanced poultry feeding $36.67 \%$, deworming $33.34 \%$, vaccination(F-1) $33.33 \%$, housing system $30.00 \%$, lime stone grit $26.67 \%$, grazing $23.34 \%$ and azolla feeding $20.00 \%$ respectively. It was revealed that azolla cultivation and feeding technologies are very popular among poultry farmers and farmers are gaining knowledge about year-round production of azolla in their own farm itself under natural atmosphere. The overall adoption percentage by the farmers indicated that training had significant impact on uptake of new technologies.

\section{Introduction}

Poultry farming has now become a remunerative business and pre-eminence over all other livestock enterprises in the developing countries. Backyard poultry farming play an important role in the economic development of the country. In general, economic development refers to a process of upward changes of human resources which can be improved through increasing knowledge and attitude level of the rural take holders. Training is an integral and crucial input for the human resources development in all walks of life, be it agriculture, poultry rearing, animal husbandry, fisheries or any other field for bringing out desirable changes in human 
behavior (Biswas et al., 2008). Poultry is one of the subsidiaries for economic and social up liftment in agriculture sector. The backyard poultry production is an age old practice in rural India. Most of the backyard poultry production comprises rearing of indigenous birds with poor production performances. The potentiality of indigenous birds in terms of egg production is only 50 to 70 eggs/ bird/ year and meat production is also very less. However, the backyard poultry production can be geared- up with improved variety of poultry and can promise a better production of meat and egg. Among traditional farmers, backyard poultry is a handy enterprise with low-cost initial investment, but high economic return along with guarantee for improving protein deficiency among the poor.

The concept of training programmes in scientific method of Backyard poultry farming through KVK Raichur substantially due to greater demand for improved poultry science technology by the farmers. Poultry population plays an important role in the national economy and socio-economic development of the landless, small and marginal farmers by supplementing family income and generating employment.

Most of the farmers are rearing poultry under traditional pattern and lack of scientific knowledge. Therefore, the present study was undertaken with the following specific objective to study the impact of training parted by ICAR-KVK, Raichur on scientific method of backyard poultry farming and feeding practices on its beneficiaries.

\section{Materials and Methods}

The study was carried out at Hyderbad Karnataka (H-K) region ICAR-Krishi Vigyan Kendra, Raichur selected the village Jakkaladinni, Manvi (Tq), Raichur (Dist) since it is the adopted village by KAPC, Karnataka, India (Table-1). The village was selected because of large number of small and marginal farmers were participated in KVK's training programme. Hands on on-campus training programmes were conducted on feeding, breeding and disease management under scientific dairy farming at $\mathrm{KVK}$, Raichur. Participants took interest and eagerly participated in training programme. Predetermined questionnaire supplied to trainees (rural youth farmers and farm women) participated in trainings organized at KVK to know and record their experiences. Offcampus training programmes also organized for 30 beneficiary farmers to visit their farm and confirm their adoption regarding scientific method of backyard poultry farming at farm level. During off campus trainings data were collected through personal contacts with the help of well-structured interview schedule.

At end of training programme feedback collected from trainees. Inputs like anthelmintic durg, balanced poultry feed and azolla culture and training materials were supplied. The selection of beneficiaries was done based on previous three years poultry farming trainings conducted by KVK Raichur from 2016 to 2019.

The data collected were processed, tabulated, classified and analyzed in terms of percentage in the light of objectives of the study. Total practices were selected to find out the extent of knowledge and adoption of scientific method of backyard poultry farming.

\section{Results and Discussion}

Extent of gain in knowledge about scientific practices in backyard poultry

The gain in knowledge by the respondents about scientific methods of backyard poultry 
farming and azolla feeding was measured in terms of percentage. The data regarding gain in knowledge about scientific method of backyard poultry farming and feeding technologies were recorded under two heads i.e. knowledge before training and after training.

The data presented in the Table 2 with regards to the level of gain in knowledge revealed that, the beneficiary farmers of backyard poultry farming training programmes gained highest knowledge about new variety $(96.67 \%)$. It was also found that a majority of the backyard poultry farmers gained highest knowledge about housing system (semi intensive and intensive) (93.33\%) followed by balanced poultry feed $(90.00 \%)$, vaccination (F-1) (83.33\%), deworming (76.67\%), lime stone grit $(63.33 \%)$, Scavenging habit $(56.67 \%)$ and azolla feeding $(40.00 \%)$.

The findings are in confirmation with the results of the research studies conducted by Verma et al., (2018) revealed that training has a definite impact on the knowledge level of the respondents. This might be due to the fact that they were convinced through training programmes about scientific method of backyard poultry farming and azolla feeding by KVK, which were designed to import latest knowledge through work experience.

Table.1 Selection of farmers from different blocks of adopted village

\begin{tabular}{|c|c|c|}
\hline S.No & Name of the Block & Name of the Village \\
\hline 1 & Manavi (Sirwar) & Jakkaladinni \\
\hline
\end{tabular}

Table.2 Distribution of respondents according to Gain in knowledge about scientific method of backyard poultry farming and the feeding technology $(n=30)$

\begin{tabular}{|c|c|c|c|c|c|}
\hline \multirow{2}{*}{$\begin{array}{l}\text { Sl. } \\
\text { No }\end{array}$} & \multirow{2}{*}{ Technologies } & \multicolumn{2}{|c|}{ Gain in knowledge (Nos.) } & \multicolumn{2}{|c|}{ Gain in knowledge (\%) } \\
\hline & & $\begin{array}{l}\text { Before } \\
\text { training }\end{array}$ & $\begin{array}{c}\text { After } \\
\text { training }\end{array}$ & $\begin{array}{l}\text { Before } \\
\text { training }\end{array}$ & $\begin{array}{l}\text { After } \\
\text { training }\end{array}$ \\
\hline 1 & $\begin{array}{l}\text { Housing system } \\
\text { (Semi intensive, } \\
\text { Intensive) }\end{array}$ & 19 & 28 & 63.33 & 93.33 \\
\hline 2 & New Variety(Giriraj) & 17 & 29 & 56.67 & 96.67 \\
\hline 3 & $\begin{array}{l}\text { Balanced poultry } \\
\text { feed }\end{array}$ & 16 & 27 & 53.33 & 90.00 \\
\hline 4 & Vaccination (F-1) & 15 & 25 & 50.00 & 83.33 \\
\hline 5 & Deworming & 13 & 23 & 43.33 & 76.67 \\
\hline 6 & $\begin{array}{l}\text { Lime stone grit } \\
\text { feeding }\end{array}$ & 11 & 19 & 36.67 & 63.33 \\
\hline 7 & Scavenging habit & 10 & 17 & 33.33 & 56.67 \\
\hline 8 & Azolla feeding & 6 & 12 & 20.00 & 40.00 \\
\hline
\end{tabular}


Table.3 Distribution of respondents according to Adoption about scientific method of backyard poultry farming and the feeding technology $(n=30)$

\begin{tabular}{|c|c|c|c|c|}
\hline \multirow[t]{2}{*}{ Sl. No } & \multirow{2}{*}{ Technologies } & \multicolumn{2}{|c|}{ Level of Adoption (\%) } & \multirow{2}{*}{$\begin{array}{c}\text { Adoption Leve } \\
\text { Increase (\%) } \\
\text { After training }\end{array}$} \\
\hline & & $\begin{array}{c}\text { Before } \\
\text { training }\end{array}$ & $\begin{array}{c}\text { After } \\
\text { training }\end{array}$ & \\
\hline $\mathbf{1}$ & $\begin{array}{l}\text { Housing system } \\
\text { (Semi intensive, } \\
\text { Intensive) }\end{array}$ & 63.33 & 93.33 & 30.00 \\
\hline 2 & New Variety(Giriraj) & 56.67 & 96.67 & 40.00 \\
\hline 3 & $\begin{array}{l}\text { Balanced poultry } \\
\text { feed }\end{array}$ & 53.33 & 90.00 & 36.67 \\
\hline 4 & Vaccination $(\mathrm{F}-1)$ & 50.00 & 83.33 & 33.33 \\
\hline 5 & Deworming & 43.33 & 76.67 & 33.34 \\
\hline 6 & Lime stone grit & 36.67 & 63.33 & 26.67 \\
\hline 7 & Scavenging habit & 33.33 & 56.67 & 23.34 \\
\hline 8 & Azolla feed & 20.00 & 40.00 & 20.00 \\
\hline
\end{tabular}

Extent of adoption of scientific practices in backyard poultry

With regards to the level of adoption, beneficiary farmers of backyard poultry farming training programmes the data presented in the Table 3 revealed that before training very few farmers were following the scientific method of backyard poultry farming and azolla feeding. Like housing system (Semi intensive, Intensive) 63.33\%, new variety $56.67 \%$, balanced poultry feed $53.33 \%$, vaccination (F1)50.00\%, deworming $43.33 \%$, lime stone grit $36.67 \%$, grazing $33.33 \%$ and very less of the farmers were adopted azolla feeding(2.00\%)before acquiring training.

Whereas, after attending training programme the adoption level increased in new variety $40.00 \%$, balanced poultry feeding $36.67 \%$, deworming 33.34\%, vaccination ( $\mathrm{F}-$ 1), $33.33 \%$, housing system $30.00 \%$, lime stone grit $26.67 \%$, Scavenging $23.34 \%$ and azolla feeding $20.00 \%$ respectively. These findings are also in support with Verma, et al., (2018), who concluded that training, had positive impact on the farmer's perception and performance. The results were in agreement with Biswas et al., (2008) who reported that the effect of training on backyard poultry farming practices and indicated that backyard poultry training programme had a significant difference in knowledge of respondents in scientific practices like deworming, feeding and vaccination.

In present study it was concluded that the training program has a tremendous impact on the farmers on adoption of scientific method of backyard poultry farming. Among different parameters new variety (Giriraj) had highest level of adoption percentage (40.00\%) and least adoption percentage in azolla feeding practice $(20.00 \%)$ was observed. It was revealed that azolla cultivation and feeding technologies are much popular among poultry farmers and farmers are gaining knowledge about year-round production of azolla in their 
own farm itself under natural atmosphere. Azolla can be considered as part of feed replacing $25 \%$ of balanced feed. The overall adoption percentage by the farmers indicated that training had a significant impact in uptake of new technologies thereby increasing their livelihood with renewed income.

The training imparted to farmers increased the awareness about new technologies among the beneficiaries and increased their knowledge. As most of the poor and marginal farmers have very limited capital assets and they mostly depend on poultry farming for their livelihoods.

Therefore it is very much necessary to raise awareness about this activity. Besides reduction of poverty it will help in nutritional improvement especially in vulnerable groups. It not only gives employment to the rural small scale and marginal farmers but also plays an important role in women empowerment.

\section{References}

Ali J., (2007). Livestock sector development and implications for rural poverty alleviation in India, Livest. Res. Rural Dev., 19(2).

Biswas, S., A. Sarkar and A. Goswami (2008). Impact of KVK training on advance dairy farming practices (AFDPS) in changing knowledge and attitude of Prani-Bandhu.J.Dairying Foods Home Sci., 27(1):p43-46.

Pradeepta Kumar Rath, KrutiDebnathMandal and Pratikshya Panda (2015).Backyard Poultry Farming In India: A Call for Skill Upliftment: Research Journal of Recent Sciences., Vol. 4, IVC-, p1-5.

Verma, L.C.; R. Nayak. S.K. Sachan, Rudra P. and Singh, R. K. Anand (2018). Impact of KVK trainings in promotion of scientific dairy farming in Azamgarh district. Progressive research $-A n$ International journal, Vol. 13, (Special).

\section{How to cite this article:}

Pralhad, G. S. Yadahalli, Nagaraj, J. N. Sreedhara, C. Anupama, G. N. Shreevani and Patil. M. C. 2020. Impact of KVK Trainings on Promotion of Backyard Poultry Farming In KalyanKarnataka, India. Int.J.Curr.Microbiol.App.Sci. 9(06): 407-411. doi: https://doi.org/10.20546/ijcmas.2020.906.053 